\title{
Diversity of phytoplankton community in different urban aquatic ecosystems in metropolitan Joáo Pessoa, state of Paraíba, Brazil
}

\author{
Diversidade da comunidade fitoplactônica em diferentes ecossistemas aquáticos urbanos \\ da região metropolitana de João Pessoa, PB, estado da Paraíba, Brasil
}

\section{Davi Freire da Costa and Ênio Wocyli Dantas}

Centro de Ciências Biológicas e Sociais Aplicadas, Universidade Estadual da Paraíba - UEPB, Rua Horácio Trajano de Oliveira, s/n, Cristo, CEP 58070-450, João Pessoa, PB, Brazil email: davifreirecosta@yahoo.com.br; eniowocyli@yahoo.com.br

\begin{abstract}
Aim: The aim of the present study was to identify which environmental factors affect the seasonal phytoplankton structure in different types of tropical aquatic ecosystems. Phytoplankton sampling was performed bi-monthly from August 2009 to June 2110 at three sites in the Solon de Lucena Lake, Jaguaribe River and Águas Minerais reservoir. Methods: The environmental variables were water temperature, transparency, depth, degree of infestation of aquatic macrophytes, air temperature, wind speed, solar radiation and precipitation. The phytoplankton community was studied in terms of richness, density, diversity and evenness. The data were treated with analysis of variance and canonical correspondence analysis. Results: Spatial variations in the data only occurred between ecosystems $(\mathrm{p}<0.05)$. The reservoir and river exhibited typical phytoplankton of lotic environments, with a greater richness of Bacillariophyta $(52.8 \%$ and $47.8 \%$, respectively). The lake exhibited the typical richness lentic environments, with the greatest contribution from Chlorophyta $(52.8 \%)$. This ecosystem was characterized by an absence of macrophytes, a low degree of water transparency $(0.3 \pm 0 \mathrm{~m})$ and high algal density $\left(89,903 \pm 38,542\right.$ ind. $\left.\mathrm{mL}^{-1}\right)$, with a dominance of Aphanocapsa nubilum. In the river environment, the lesser diversity $\left(0.64 \pm 0.24\right.$ bit.ind $\left.^{-1}\right)$ was associated to lesser richness $(2.4 \pm 0.5 \mathrm{spp}$. $)$ and lesser evenness $(0.39 \pm 0.19)$ in comparison to the other ecosystems. The influence of macrophytes in the river and reservoir contributed toward the introduction of metaphytes and epiphytes in the phytoplankton, which was explained by the direct relationship between the density of these species and macrophytes. Conclusion: Thus, water transparency and macrophytes were the main factors related to fluctuations between the different aquatic ecosystems studied.
\end{abstract}

Keywords: abiotic factors, aquatic macrophytes, phytoplankton, tropical water systems.

Resumo: Objetivo: Este trabalho visou identificar que fatores ambientais interferem na estrutura sazonal fitoplanctônica em diferentes tipos de ecossistemas aquáticos tropicais. Coletas do fitoplâncton foram realizadas bimestralmente de agosto/2009 até junho/2010 em três pontos na lagoa Solon de Lucena, no rio Jaguaribe e no reservatório das Águas Minerais. Métodos: As variáveis ambientais utilizadas neste estudo foram temperatura e transparência da água, profundidade, níveis de infestação de macrófitas aquáticas, temperatura do ar, velocidade do vento, radiação solar e precipitação pluviométrica. A comunidade fitoplanctônica foi estudada em nível de riqueza, densidade, diversidade e equitatividade. Os dados foram tratados através de análise de variância e ACC. Resultados: A variação espacial dos dados foi observada apenas entre os ecossistemas $(\mathrm{p}<0,05)$. O reservatório e o rio apresentaram fitoplâncton típico de ambientes lóticos com maior riqueza de Bacillariophyta (52,8\% e 47,8\%, respectivamente). Entretanto, a lagoa apresentou riqueza típica de ambientes lacustres com maior contribuição de Chlorophyta $(52,8 \%)$. Este ecossistema diferente dos demais foi caracterizado pela ausência de macrófitas, baixa transparência da água $(0,3 \pm 0 \mathrm{~m})$ e elevada densidade algal $\left(89.903 \pm 38.542\right.$ ind. $\left.\mathrm{mL}^{-1}\right)$, com dominância Aphanocapsa nubilum. No rio uma menor diversidade $\left(0,64 \pm 0,24\right.$ bit.ind $\left.^{-1}\right)$ foi associada à menor riqueza $(2,4 \pm 0,5 \mathrm{spp}$. $)$ e à menor equitatividade $(0,39 \pm 0,19)$ comparados aos outros ecossistemas. A influência de macrófitas no rio e no reservatório contribuiu para a introdução de espécies metafíticas e epifíticas no fitoplâncton, o que foi explicado pela relaçáo direta da densidade destas espécies com as macrófitas. Conclusão: Assim, a transparência da água e macrófitas foram os principais fatores relacionados com as flutuaçóes do fitoplâncton entre os diferentes tipos de ecossistemas aquáticos estudados.

Palavras-chave: fatores abióticos, macrófitas aquáticas, fitoplâncton, sistemas hídricos tropicais. 


\section{Introduction}

Knowledge regarding the interactions phytoplankton establishes with environmental factors is important to the investigation of the role this community plays in the structuring of aquatic ecosystems. The study of these interactions in the tropics has been infrequent in the general theoretical discussions. This is partially due to the scarcity of investigations carried out in tropical regions in comparison to the large number of studies on temperate regions (Bozelli and Huszar, 2003). Moreover, tropical studies of this nature have been carried out in an isolated fashion in lakes (e.g., Taniguchi et al., 2003; Nogueira et al., 2005), rivers (e.g., Train et al., 2000; Soares et al., 2007) and reservoirs (e.g., Pompêo et al., 1998; Moura et al., 2007), with a lack of comparative studies between these ecosystems.

In the tropics, abiotic factors such as air temperature and light tend to be constant throughout the year and other environmental factors influence fluctuations in phytoplankton communities (Espíndola et al., 1996). Together with rainfall, fluctuations in water level and water flow, wind is an important factor in lakes and reservoirs by influencing the distribution of nutrients and light, sedimentation rate and transparency (Espíndola et al., 1996; Moura et al., 2007). Rainfall and flow rate are important in rivers, as these factors are related to turbulence and limitations to light (Train et al., 2000; Ferrareze and Nogueira, 2006).

With regard to biotic factors, aquatic macrophytes exert an influence over the ecology of algae through the promotion of habitat heterogeneity as well as through competition for nutrients and the action of allelopathic substances and cascading mechanisms, such as predation on phytoplankton by zooplankton, which use macrophytes as shelter (Ozimek et al., 1990; Gross, 2003).

In temperate ecosystems, the abundance of algae varies with fluctuations in environmental factors between different types of systems, specifically as a result of dissimilarities in the horizontal movements of the water (Søballe and Kimmel, 1987). These issues need to be analyzed in tropical environments in order to gain an understanding of the factors that exert an influence over the phytoplankton dynamics between different aquatic ecosystems.

The aim of the present study was to identify the environmental factors that directly or indirectly affect the seasonal structuring of the phytoplankton in different types of tropical aquatic ecosystems.

\section{Materials and Methods}

\subsection{Ecosystems studied}

The Solon de Lucena lake ( $7^{\circ} 7^{\prime} \mathrm{S}$ and $\left.34^{\circ} 52^{\prime} \mathrm{W}\right)$ is located in the northern portion of the city of João Pessoa and is surrounded by the neighborhood denominated Centro. The lake has a volume of $80,910.32 \mathrm{~m}^{3}$ and a mean depth of $1.67 \mathrm{~m}$. This environment has landscape and tourism importance for the city. The Águas Minerais reservoir ( $7^{\circ} 7^{\prime} \mathrm{S}$ and $34^{\circ} 58^{\prime} \mathrm{W}$ ) was formed by the damming of the Mumbaba River, which is a small tributary of the lower Paraíba River basin. The reservoir is located in the neighborhood denominated Popular in the city of Santa Rita (metropolitan region of João Pessoa); it has a volume of $271,582.42 \mathrm{~m}^{3}$ and mean depth of $4.81 \mathrm{~m}$. This reservoir is an important tourist point for the city of Santa Rita and is used for both domestic and recreational purposes. The spring of the Jaguaribe River is located in the southern portion of the city of João Pessoa ( $7^{\circ} 10^{\prime} \mathrm{S}$ and $\left.34^{\circ} 53^{\prime} \mathrm{W}\right)$ and has an approximate length of $21 \mathrm{~km}$, emptying into the Atlantic Ocean ( $7^{\circ} 3^{\prime} \mathrm{S}$ and $34^{\circ} 51^{\prime} \mathrm{W}$ ) between the cities of Cabedelo and João Pessoa. Its main tributaries are the Timbó on the right bank and Macacos Stream on the left bank. However, the river receives waters from different sources between its upper course and the dam of the Benjamim Maranhão Botanical Gardens Forest Reserve (Melo, 2001) (Figure 1).

\subsection{Environmental and biological data}

Data collection was carried out bi-monthly from August 2009 to June 2110 at three points in the Solon de Lucena Lake, Jaguaribe River and Águas Minerais reservoir (Figure 1). Water temperature $\left({ }^{\circ} \mathrm{C}\right.$; using an underwater thermometer), water transparency ( $\mathrm{m}$; using a Secchi disk) and depth ( $\mathrm{m}$; using a measuring tape) were determined in situ. Macrophytes were quantified at each sampling point and categorized using a point system ranging from 0 (absence of macrophytes) to 5 (strong infestation), based on Vega (1997). The following environmental data were obtained from the National Meteorology Institute: air temperature $\left({ }^{\circ} \mathrm{C}\right)$, wind speed $(\mathrm{m} / \mathrm{s})$, solar radiation $\left(\mathrm{k} / \mathrm{m}^{2}\right)$ and precipitation $(\mathrm{mm})$. Water samples were taken directly from each sampling point, stored in $100 \mathrm{~mL}$ plastic vials and fixed in a $4 \%$ formalin solution for the subsequent determination of composition and quantification.

\subsection{Data analysis}

The analysis of algal composition was performed through the mounting of semi-permanent slides 
$34^{\circ} 58^{\prime} 26.4^{\prime \prime} \mathrm{W}$
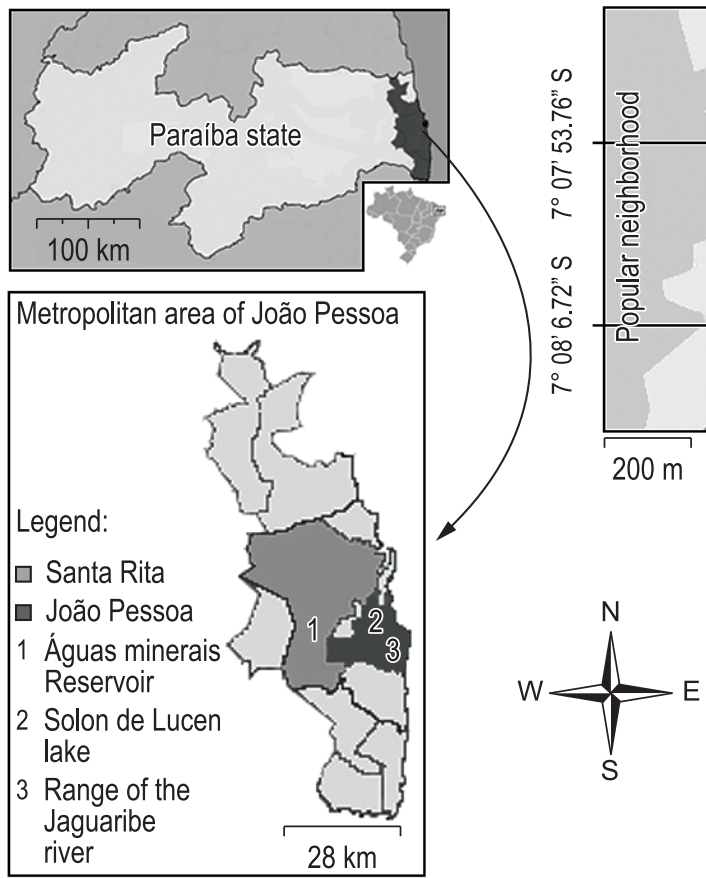

$34^{\circ} 52^{\prime} 49.44^{\prime \prime} \mathrm{W}$

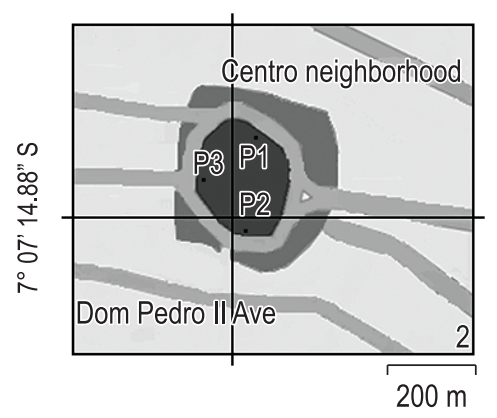

$34^{\circ} 51^{\prime} 31.68^{\prime \prime} \mathrm{W} \quad 34^{\circ} 50^{\prime} 39.84^{\prime \prime} \mathrm{W} \quad 34^{\circ} 49^{\prime} 48^{\prime \prime} \mathrm{W}$

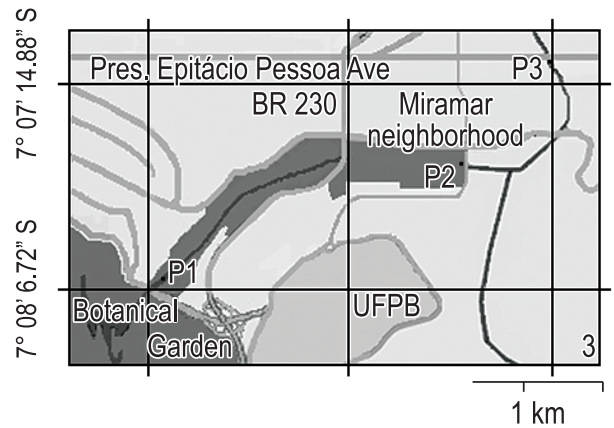

Figure 1. Location of ecosystems studies in metropolitan João Pessoa, state of Paraíba, Brazil, and respective sampling points (P1, P2 and P3).

and subsequent examination under an optical microscope. Identification was based on studies by Sant'Anna (1984), Sant'Anna et al. (2007), Silva (1999), Bicudo (2004), Biolo et al. (2009), Alves-da-Silva and Tamanaha (2008), Germain (1981), Brassac and Ludwig (2005), Landucci and Ludwig (2005) and Díaz-Castro et al. (2003). Phytoplankton counts were carried out in a Neubauer chamber (volume: $1.8 \mathrm{~mm}^{3}$ ) with the aid of an optical microscope. The calculation of density (ind. $\mathrm{mL}^{-1}$ ) was performed directly. In samples with small densities, concentrations were performed through sedimentation; in such cases, density was calculated by dividing by the concentration factor.

Richness analyses (local $-\alpha$ and regional $-\gamma$ diversity and beta diversity) were carried out based on Harrison et al. (1992). The frequency of occurrence of phytoplankton was determined based on richness data, with the organisms were classified as follows: rare $(\leq 20 \%)$, infrequent $(>20 \% \leq 50 \%)$, frequent $(>50 \% \leq 80 \%)$ and very frequent $(>80 \%)$, following the method proposed by Mateucci and Colma (1982). Species were classified as dominant when accounting for more than 50\% of the overall density (Lobo and Leighton, 1986). Specific diversity (bit.ind ${ }^{-1}$ ) was calculated based on Shannon (1948) and evenness was calculated based on Pielou (1977).
All data was treated with descriptive statistics for the determination of the variability in the environmental factors around mean values as well as variances in the spatial and temporal dimension. The spatial dimension was analyzed in each ecosystem separately as well as between ecosystems. The temporal dimension was analyzed considering the variation in a seasonal cycle established through the variation in six months sampled throughout a one-year period. Two-tailed analysis of variance (ANOVA) was employed to determine the variability of each factor in the spatial and temporal dimensions and one-tailed ANOVA was performed to determine the variability between ecosystems. Tukey's test was used to determine differences in mean values between ecosystems. For such, the BioEstat 3.0 was used (Ayres et al., 2007).

Canonical correspondence analysis (CCA) was performed to detect relationships between the density of phytoplankton species and the environmental variables analyzed in the three ecosystems. Taxa accounting for more than $10 \%$ of the overall density in at least one sampling season were included in this test, along with the environmental factors selected through the forward stepwise procedure. The Monte Carlo test with 999 permutations was performed for the analysis of the significance of the CCA axes and vectors of 
the environmental variables that defined these axes. For such, the Canoco 4.5 statistical program was used (ter Braak and Šmilauer, 2002).

\section{Results}

\subsection{Environmental factors}

The greatest amount of rainfall and lowest air temperature occurred in August 2009 except in the reservoir that had a maximum rainfall in June 2010. The wind speed showed little temporal and spatial variation in all ecosystems $(\mathrm{p}<0.05)$, with values between 2.0 and $2.4 \mathrm{~m} . \mathrm{s}^{-1}$. The highest solar radiation value occurred in October 2009 (Table 1).

Water temperature $(\mathrm{F}=33.43 ; \mathrm{p}<0.001)$, water transparency $(\mathrm{F}=48.54 ; \mathrm{p}<0.001)$ and macrophyte infestation $(\mathrm{F}=63.18 ; \mathrm{p}<0.001)$ exhibited variations between ecosystems, with the lake differing from the river and reservoir $(\mathrm{p}<0.01)$ and the latter two not differing significantly from each other $(\mathrm{p}<0.05)$.

In all months sampled the lake showed higher water temperature $\left(30.6 \pm 1.8^{\circ} \mathrm{C}\right)$ and lower water transparency $(0.3 \pm 0.0 \mathrm{~m})$ in relation to reservoir $\left(27.9 \pm 1.4^{\circ} \mathrm{C}\right.$ and $0.9 \pm 0.1 \mathrm{~m}$, respectively) and river $\left(27.0 \pm 0.5^{\circ} \mathrm{C}\right.$ and $0.8 \pm 0.2 \mathrm{~m}$, respectively) (Table 1). The aquatic plants were absent from the lake and the greatest average macrophyte infestation was found in the reservoir $(2.2 \pm 0.3)$, with a predominance of floating plants of the families Hydrocharitaceae and Pontederiaceae as well as the occurrence of Cyperaceae, Poaceae, Nymphaeaceae, Onagraceae and Salviniaceae. However, the river had higher degree of infestation in December 2009 (2.3) and April (2.3), with dominance of the family Pontederiaceae and the occurrence of Poaceae, Polygonaceae and Araceae.

\subsection{Phytoplankton community}

Gamma diversity was 59 taxa, which are listed in Table 2. Thirty-six taxa were recorded in the lake and reservoir and 23 were recorded for the river (alpha diversity). The specific composition in the lake was formed mainly by Chlorophyta (52.8\%), whereas the composition in the reservoir and river was formed mainly by Bacillariophyta $(52.8 \%$ and 47.8\%, respectively) (Figure 2a).

No significant spatial or temporal variation was found in overall richness when considering each environment separately $(\mathrm{p}<0.05)$, but spatial variation was found between ecosystems $(F=131$; $p<0.001$ ), which differed significantly from each other $(\mathrm{p}<0.05)$. The lake and river respectively had the highest $(17.0 \pm 1.7$ spp. $)$ and lowest $(2.4 \pm 0.5$ spp. $)$ overall richness over all months

Table 1. Environmental factors of ecosystems studied in metropolitan Joáo Pessoa between August 2009 and June 2010.

\begin{tabular}{|c|c|c|c|c|c|c|c|}
\hline Variable & Environment & Aug. 09 & Oct. 09 & Dec. 09 & Feb. 10 & Apr. 10 & June 10 \\
\hline & Lake & 275.8 & 48.2 & 58 & 53.8 & 64.8 & 94 \\
\hline \multirow[t]{3}{*}{ Precipitation (mm) } & Reservoir & 244.2 & 6.8 & 29.1 & 41.6 & 169.8 & 245.8 \\
\hline & River & 252.4 & 10 & 29.4 & 42.6 & 173.4 & 120.8 \\
\hline & Lake & 24.6 & 26 & 26.9 & 27.8 & 28.2 & 26.9 \\
\hline \multirow[t]{3}{*}{ Air temperature $\left({ }^{\circ} \mathrm{C}\right)$} & Reservoir & 24.7 & 26.5 & 26.9 & 28.1 & 27.6 & 26.2 \\
\hline & River & 24.7 & 26.3 & 26.9 & 27.8 & 27.6 & 26.6 \\
\hline & Lake & 2.2 & 2.3 & 2.4 & 2.3 & 2 & 2.2 \\
\hline \multirow[t]{3}{*}{ Wind speed (m/s) } & Reservoir & 2.4 & 2.3 & 2.2 & 2 & 2.1 & 2.4 \\
\hline & River & 2.3 & 2.3 & 2.2 & 2.3 & 2.1 & 2.1 \\
\hline & Lake & 786.4 & 1116.9 & 1100.1 & 858 & 909.7 & 805 \\
\hline \multirow[t]{3}{*}{ Solar radiation $\left(\mathrm{KJm}^{2}\right)$} & Reservoir & 833 & 1251.7 & 936.3 & 1015.1 & 820.5 & 870.1 \\
\hline & River & 821.1 & 1022.0 & 928.7 & 556.4 & 822.2 & 777.8 \\
\hline & Lake & 1.4 & 0.5 & 1.2 & 1.3 & 1.4 & 1.1 \\
\hline \multirow[t]{3}{*}{ Depth (m) } & Reservoir & 1.1 & 1.0 & 0.7 & 0.9 & 0.9 & 1.1 \\
\hline & River & 1.3 & 2.1 & 1.2 & 1.1 & 1.0 & 1.0 \\
\hline & Lake & 27.5 & 30.7 & 30.3 & 32.7 & 32.0 & 30.7 \\
\hline \multirow[t]{3}{*}{ Water temperature $\left({ }^{\circ} \mathrm{C}\right)$} & Reservoir & 26.2 & 27.8 & 28.0 & 29.8 & 29.0 & 26.7 \\
\hline & River & 26.2 & 26.8 & 27.0 & 27.2 & 27.8 & 27.2 \\
\hline & Lake & 0.3 & 0.2 & 0.3 & 0.3 & 0.3 & 0.3 \\
\hline \multirow[t]{3}{*}{ Water transparency (m) } & Reservoir & 1.0 & 1.0 & 0.7 & 0.9 & 0.8 & 1.0 \\
\hline & River & 1.0 & 1.0 & 0.8 & 0.9 & 0.6 & 0.7 \\
\hline & Lake & 0.0 & 0.0 & 0.0 & 0.0 & 0.0 & 0.0 \\
\hline \multirow[t]{2}{*}{ Macrophyte infestation } & Reservoir & 2.0 & 2.0 & 2.0 & 2.3 & 2.0 & 2.7 \\
\hline & River & 0.7 & 1.3 & 2.3 & 2.3 & 2.3 & 2.3 \\
\hline
\end{tabular}


(Figure 2B). The $\beta-1$ diversity index was above 50 during the study (Figure 2B).

Aphanocapsa nubilum J.Komárek \& H.Kling was the only frequent species, occurring in more than $50 \%$ of the sampling points in the lake, reservoir and river. The majority of species was rare (74.6\%), with 30 taxa occurring in only one of the ecosystems studied (Table 2).

Algal density ranged from 93 to 151.914 ind. $\mathrm{mL}^{-1}$. No spatial or temporal variation was found when considering each environment separately $(p<0.05)$. However, spatial variation was significant between environments $(F=26.75, p<0.001)$. Density in the lake $\left(89,903 \pm 38,542\right.$ ind. $\left.\mathrm{mL}^{-1}\right)$ was significantly higher $(\mathrm{p}<0.01)$ in comparison with the reservoir $\left(567 \pm 476\right.$ ind. $\left.\mathrm{mL}^{-1}\right)$ and river $\left(384 \pm 344\right.$ ind. $\left.\mathrm{mL}^{-1}\right)$ (Figure 3).

Cyanophyta was the most abundant group in the lake and river in the majority of months. A. nubilum, a representative of this group, was dominant in April 2010 in the lake and August 2009 in the river, causing density peaks in these ecosystems. The second dominance event in the river was caused by the cyanophyte Geitlerinema unigranulatum (R.N.Singh) J.Komárek \& M.T.P. Azevedo in April 2010. With the exception of October 2009, Bacillariophyta accounted for the greatest density values in the phytoplankton in the reservoir. The greatest overall density in this environment was found in December 2009, when the most abundant taxa were Eunotia sp., Navicula dicephala Ehrenberg (Figure 3 and Table 3 ).

Diversity values ranged from 0.37 bit.ind $^{-1}$ to 2.45 bit.ind $^{-1}$, which is considered far below average. No significant variation in specific diversity was found between sampling points and the months studied when considering each ecosystem separately $(\mathrm{p}<0.05)$. However, variation was found between environments $(\mathrm{F}=36.95, \mathrm{p}<0.001)$, which differed significantly from each other $(\mathrm{p}<0.01)$. The lake had the highest diversity values $(2.19 \pm 0.25$ bit. ind $\left.^{-1}\right)$, following by the reservoir $(1.29 \pm 0.47$ bit. ind $\left.^{-1}\right)$ and river $\left(0.64 \pm 0.24\right.$ bit.ind $\left.^{-1}\right)$.

Evenness ranged from 0.18 to 0.67 , with a statistically significant difference between ecosystems $(\mathrm{F}=3.63 ; \mathrm{p}<0.05)$; the reservoir differed from the river $(p<0.05)$, whereas the evenness in the lake was similar to the values found in the reservoir and river $(\mathrm{p}<0.05)$. The reservoir exhibited the greatest evenness $(0.57 \pm 0.12)$, followed by the lake $(0.54 \pm 0.06)$ and river $(0.39 \pm 0.19)$. No variation was found between sampling points in each environment $(p<0.05)$. The lake was the only ecosystem to exhibit temporal variation $(\mathrm{F}=4.56$; $\mathrm{p}<0.05$ ), with the lowest evenness values occurring in April 2010, when A. nubilum was dominant.

CCA using the Monte Carlo test revealed that both Axis 1 and all axes proved significant $(\mathrm{p}<0.01)$. The first two ordination axes together explained $35.8 \%$ of the variation in species (Table 4). Axis 2 expressed the temporal variability

(a)
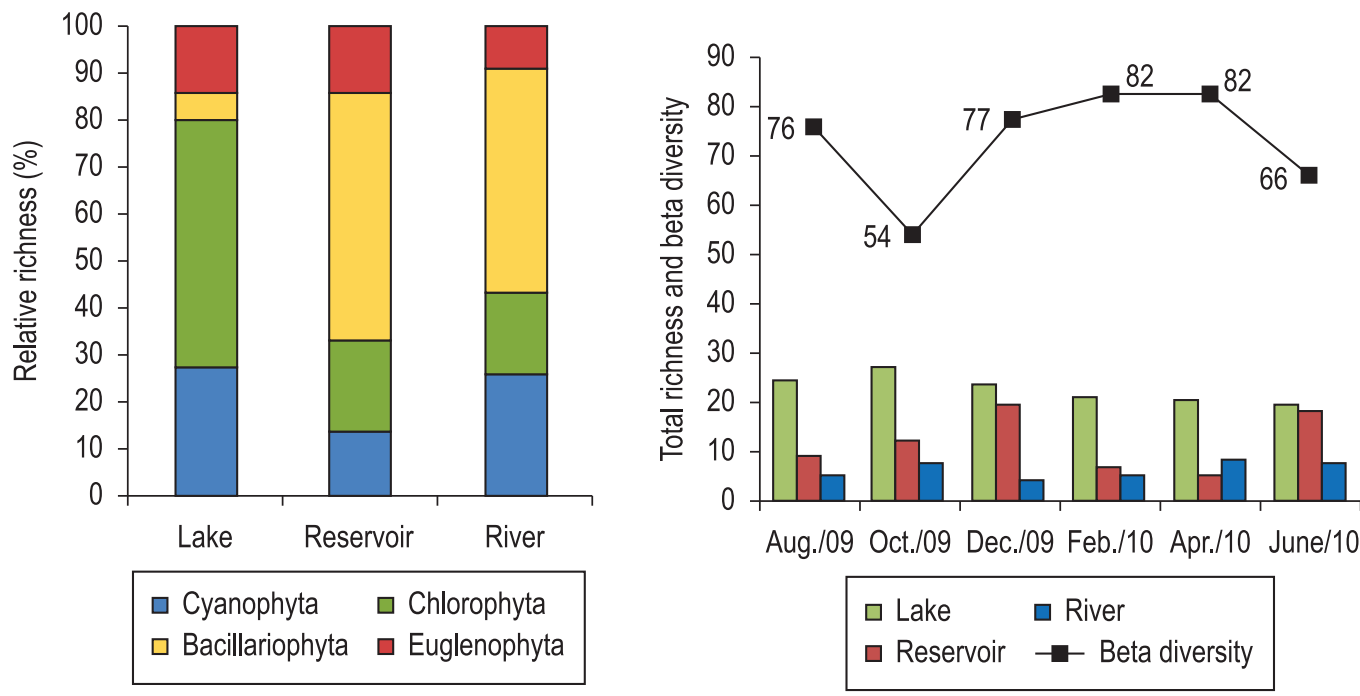

Figure 2. Relative richness of phytoplankton groups (a), total richness and beta diversity (b) in Solon de Lucena Lake, Águas Minerais reservoir and Jaguaribe River in metropolitan João Pessoa, PB, Brazil between Aug 2009 and June 2010. 
Table 2. List of phytoplankton taxa and frequency of occurrence of species in Solon de Lucena Lake, Águas Minerais reservoir and Jaguaribe River in metropolitan João Pessoa, PB, Brazil between Aug 2009 and June 2010; Legend: $\mathrm{FO}=$ frequency of occurrence, $\mathrm{R}=$ rare species, $\mathrm{IF}=$ infrequent species, $\mathrm{F}=$ frequent species, $\mathrm{A}=$ Aug $09, \mathrm{O}=$ October 09, D = December 09, F = February 10, B = April 10, J = June 10.

\begin{tabular}{|c|c|c|c|c|c|c|c|}
\hline & & Lagoa & & & Reser & atóric & \\
\hline & A 0 & $D \quad F$ & $\mathbf{J}$ & A & $\begin{array}{ll}\text { D } \\
\end{array}$ & $F \quad B$ & \\
\hline
\end{tabular}

\section{Cyanophyta}

Anabaena flos-aquae

Brébisson ex Bornet \& Flauhault

Aphanocapsa nubilum

J.Komárek \& H.Kling

Chroococcus dispersus

(Keissler) Lemmermann

C. limneticus Lemmermann

Chroococcus sp.

Cylindrospermopsis sp.

Geitlerinema unigranulatum

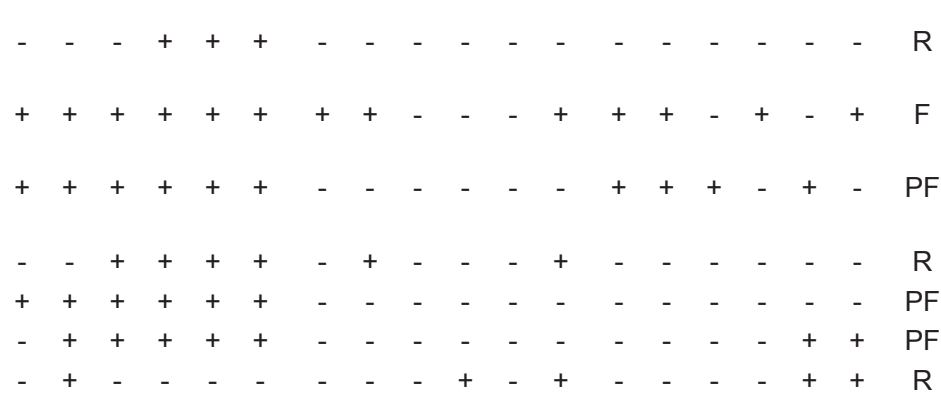

(R.N.Singh) J.Komárek \&

M.T.P.Azevedo

Merismopedia sp.

Oscillatoria sp.

Pseudanabaena sp.

\section{Chlorophyta}

Chlorella vulgaris Beijerinck

Chlamydomonas sp.

Coelastrum astroideum De Notaris

Crucigenia fenestrata (Schmidle)

Schmidle

Crucigenia quadrata Morren

Dictyosphaerium pulchellum

H.C.Wood

Keratococcus sp.

Kirchneriella lunaris (Kirchner)

K.Möbius

Monoraphidium arcuatum

(Korshikov) Hindák

M.contortum (Thuret)

Komàrková-Legnerová

M. griffithii (Berkeley)

Komárková-Legnerová

Sphaerocystis schroeteri Chodat

Pediastrum tetras (Ehrenberg)

Ralfs

Scenedesmus acuminatus

(Lagerheim) Chodat

S. arcuatus Lemmermann

S. bicaudatus (Hansgirg) Chodat

S. decorus Hortobágyi

S. ecornis (Ehrenberg) Chodat

S. quadricauda Chodat

Tetraedron minimum (A.Braun)

Hansgirg

Volvox sp.

\section{Bacillariophyta}

Amphora veneta Kützing

Cyclotella sp.

Cymbella gracilis (Rabenhorst) Cleve

C. ventricosa C.Agardh

Diploneis ovalis (Hilse) Cleve

Eunotia diodon Ehrenberg

E. pectinalis (Kützing) Rabenhorst
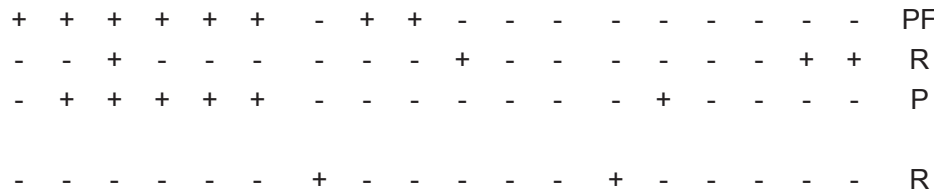

$-\quad-+++-\quad-\quad-\quad-\quad-\quad-\quad-\quad-\quad-R$

$+++-\quad-\quad-\quad-\quad-\quad-\quad-\quad-\quad-\quad-\quad-\quad-\quad-\quad-\quad-R$

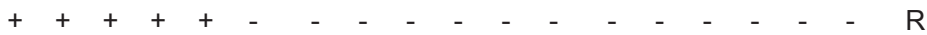

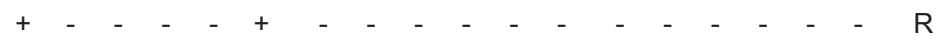

$++++++-\quad-\quad-\quad-\quad-\quad-\quad-\quad-\quad-\quad-$ PF

$-\quad-\quad+\quad+\quad-\quad-\quad-\quad-\quad-\quad-\quad-\quad-\quad-\quad-\quad-R$

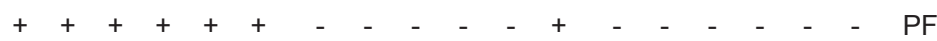

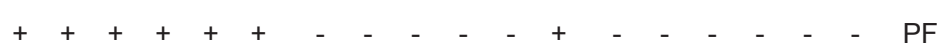

$++++++-\quad-\quad+-\quad-\quad-\quad-\quad+-\quad-$ PF

PF

$\mathrm{R}$

$R$

R

R

R

R

PF

R

$R$

R

R

R

R

R

$R$ 
Table 2. Continued...

\begin{tabular}{|c|c|c|c|c|c|c|c|c|c|c|c|c|c|c|c|c|c|c|c|}
\hline \multirow{2}{*}{ Táxon } & \multicolumn{6}{|c|}{ Lagoa } & \multicolumn{6}{|c|}{ Reservatório } & \multicolumn{6}{|c|}{ Rio } & \multirow[b]{2}{*}{ FO } \\
\hline & A & 0 & D & $\mathbf{F}$ & B & $\mathbf{J}$ & A & 0 & D & $\mathbf{F}$ & B & $\mathbf{J}$ & A & 0 & D & $\mathbf{F}$ & B & $\mathbf{J}$ & \\
\hline Eunotia sp.1 & - & - & - & - & - & - & - & - & + & + & - & + & - & - & - & - & - & - & $\mathrm{R}$ \\
\hline Eunotia sp.2 & - & - & - & - & - & - & - & - & - & + & - & - & - & - & - & - & - & - & $\mathrm{R}$ \\
\hline Fragilaria sp. & - & - & - & - & - & - & - & - & - & - & - & + & - & - & - & - & - & - & $\mathrm{R}$ \\
\hline $\begin{array}{l}\text { Frustulia rhomboides } \\
\text { (Ehrenberg) De Toni }\end{array}$ & - & - & - & - & - & - & - & - & + & - & - & - & - & - & - & - & - & - & $\mathrm{R}$ \\
\hline F. vulgaris (Thwaites) De Toni & - & - & - & - & - & - & - & - & + & - & - & - & - & - & - & - & - & - & $\mathrm{R}$ \\
\hline Gomphonema sp. & - & - & - & - & - & - & - & - & - & - & - & - & - & - & - & - & + & - & $\mathrm{R}$ \\
\hline Navicula dicephala Ehrenberg & - & - & - & - & - & - & + & + & + & + & + & + & - & - & - & - & + & + & PF \\
\hline Navicula radiosa Kützing & - & + & - & - & - & - & + & - & + & - & - & + & - & + & - & - & - & - & $\mathrm{R}$ \\
\hline Navicula sp. & - & - & - & - & - & - & - & - & + & - & - & + & - & - & - & - & + & - & $\mathrm{R}$ \\
\hline Orthoseira sp. & - & - & - & - & - & - & - & - & - & - & - & - & - & - & - & - & + & - & $\mathrm{R}$ \\
\hline Pinnularia sp.1 & - & - & - & - & - & - & - & - & + & - & - & - & - & - & - & - & - & - & $\mathrm{R}$ \\
\hline Pinnularia sp.2 & - & - & - & - & - & - & - & - & + & - & - & - & - & - & - & - & - & + & $\mathrm{R}$ \\
\hline Synedra minuscula Grunow & - & + & - & - & - & - & + & + & + & - & + & + & - & + & + & + & - & - & PF \\
\hline S. ulna (Nitzsch) Ehrenberg & - & - & - & - & - & - & - & - & - & - & - & + & - & + & - & - & - & - & $\mathrm{R}$ \\
\hline \multicolumn{20}{|l|}{ Euglenophyta } \\
\hline Euglena sp.1 & - & - & - & - & - & - & - & - & - & - & - & - & + & - & - & - & - & - & $\mathrm{R}$ \\
\hline Euglena sp. 2 & - & - & - & - & - & - & + & - & - & - & - & - & - & - & - & - & - & + & $\mathrm{R}$ \\
\hline $\begin{array}{l}\text { Trachelomonas hispida (Perty) } \\
\text { F.Stein }\end{array}$ & - & + & - & - & - & - & - & + & + & - & - & + & - & - & - & - & - & - & $\mathrm{R}$ \\
\hline T. oblonga Lemmermann & + & + & + & + & - & - & - & + & - & - & - & + & - & - & - & - & - & - & $\mathrm{R}$ \\
\hline T. volvocina Ehrenberg & + & + & + & + & + & + & + & + & + & - & + & + & - & - & - & - & - & - & PF \\
\hline T. volvocinopsis Swirenko & - & + & - & + & + & - & - & + & - & - & - & - & - & - & - & - & - & - & $\mathrm{R}$ \\
\hline Trachelomonas sp. & + & + & - & - & - & - & - & - & - & - & - & - & - & - & - & - & - & - & $\mathrm{R}$ \\
\hline
\end{tabular}
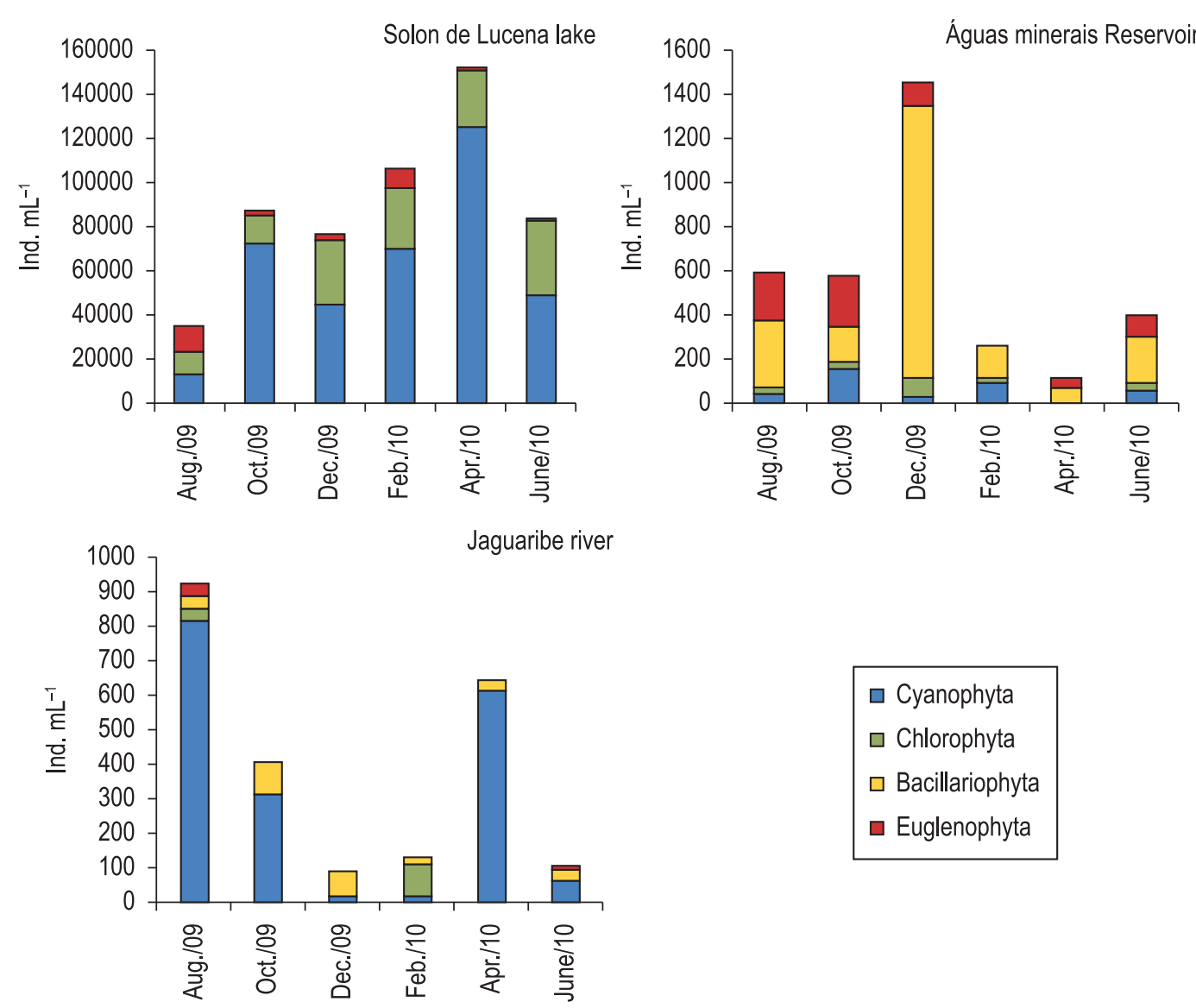

$$
\begin{aligned}
& \square \text { Cyanophyta } \\
& \square \text { Chlorophyta } \\
& \square \text { Bacillariophyta } \\
& \square \text { Euglenophyta }
\end{aligned}
$$

Figure 3. Density of phytoplankton groups in ecosystems of metropolitan João Pessoa, PB, Brazil in study between Aug 2009 and June 2010. 
Table 3. Relative abundance (\%) of most representative species in Solon de Lucena Lake, Águas Minerais reservoir and Jaguaribe River in metropolitan João Pessoa, PB, Brazil between Aug 2009 and June 2010; Legend: A = August 2009; O = October 2009; D = December 2009; F = February 2010; P = April 2010; J = June 2010; - = absence; bold type $=$ most representative species using density above $10 \%$ as criterion.

\begin{tabular}{|c|c|c|c|c|c|c|c|c|c|c|c|c|c|c|c|c|c|c|}
\hline \multirow{2}{*}{ Taxon } & \multicolumn{6}{|c|}{ Lake } & \multicolumn{6}{|c|}{ Reservoir } & \multicolumn{6}{|c|}{ River } \\
\hline & A & 0 & D & $\mathbf{F}$ & $\mathbf{P}$ & $\mathbf{J}$ & $\mathbf{A}$ & 0 & D & $\mathbf{F}$ & $\mathbf{P}$ & $\mathbf{J}$ & A & 0 & $\mathbf{D}$ & $\mathbf{F}$ & $\mathbf{P}$ & $\mathbf{J}$ \\
\hline \multicolumn{19}{|l|}{ Cyanophyta } \\
\hline Aphanocapsa nubilum & 13 & 47 & 8 & 17 & 52 & 19 & 6 & 6 & - & - & - & 2 & 84 & 64 & - & 14 & - & 7 \\
\hline Chroococcus dispersus & 2 & 4 & 3 & 11 & 8 & 9 & - & - & - & - & - & - & 4 & 9 & 20 & 0 & 2 & 0 \\
\hline Cylindrospermopsis sp. & - & 13 & 18 & 14 & 6 & 11 & - & - & - & - & - & - & - & - & - & - & 1 & 7 \\
\hline Geitlerinema unigranulatum & - & 1 & - & - & - & - & - & - & - & 14 & - & 7 & - & - & - & - & 87 & 14 \\
\hline Merismopedia sp. & 19 & 14 & 11 & 8 & 10 & 8 & - & 16 & 1 & - & - & - & - & - & - & - & - & - \\
\hline Oscillatoria sp. & - & - & 1 & - & - & - & - & - & - & 21 & - & - & - & - & - & - & - & 21 \\
\hline Pseudanabaena sp. & - & 0 & 11 & 3 & 0 & 2 & - & - & - & - & - & - & - & 5 & - & - & - & - \\
\hline \multicolumn{19}{|l|}{ Chlorophyta } \\
\hline Dictyosphaerium pulchellum & 5 & 3 & 5 & 2 & 0 & 11 & - & - & - & - & - & - & - & - & - & - & - & - \\
\hline Keratococcus sp. & - & - & - & 4 & 3 & 18 & - & - & - & - & - & - & - & - & - & - & - & - \\
\hline Monoraphidium contortum & 1 & 1 & 11 & 5 & 3 & 2 & - & - & - & 7 & - & - & - & - & - & 14 & - & - \\
\hline M. griffith & 1 & 2 & 3 & 1 & 0 & 1 & - & 6 & 6 & - & - & - & - & - & - & 43 & - & - \\
\hline S. bicaudatus & 1 & 0 & 0 & - & - & - & - & - & - & - & - & - & - & - & - & 14 & - & - \\
\hline \multicolumn{19}{|l|}{ Bacillariophyta } \\
\hline Cyclotella sp. & - & - & - & - & - & - & - & - & 1 & - & 40 & - & - & - & - & - & - & - \\
\hline Diploneis ovalis & - & - & - & - & - & - & - & - & 3 & - & - & - & - & - & 20 & - & - & - \\
\hline Eunotia pectinalis & - & - & - & - & - & - & 19 & - & 5 & - & - & 9 & 4 & - & 40 & - & - & - \\
\hline Eunotia sp. & - & - & - & - & - & - & - & - & 15 & 7 & - & 4 & - & - & - & - & - & - \\
\hline Navicula dicephala & - & - & - & - & - & - & 6 & 13 & 15 & 36 & 7 & 9 & - & - & - & - & 1 & 21 \\
\hline Synedra minuscula & - & 0 & - & - & - & - & 13 & 10 & 8 & - & 7 & 9 & - & 9 & 20 & 14 & - & - \\
\hline \multicolumn{19}{|l|}{ Euglenophyta } \\
\hline Euglena sp.2 & - & - & - & - & - & - & 13 & - & - & - & - & - & - & - & - & - & - & 7 \\
\hline Trachelomonas volvocina & 27 & 1 & 3 & 2 & 0 & 1 & 25 & 16 & 3 & - & 40 & 22 & - & - & - & - & - & - \\
\hline Other algae & 31 & 14 & 26 & 33 & 17 & 18 & 19 & 32 & 43 & 14 & 7 & 37 & 8 & 14 & - & 0 & 8 & 22 \\
\hline
\end{tabular}

Table 4. Summary of CCA indicating correlation and accumulated variance on Axes 1 and 2, demonstrating significance of first and all axes.

\begin{tabular}{|c|c|c|c|c|}
\hline & & Axis 1 & & Axis 2 \\
\hline Eigenvalues & & 0.465 & & 0.146 \\
\hline Species-environment correlation & & 0.935 & & 0.762 \\
\hline \multicolumn{5}{|l|}{ Accumulated variance (\%): } \\
\hline Species data & & 27.3 & & 35.8 \\
\hline Species-environment relation & & 76.1 & & 100.0 \\
\hline \multicolumn{5}{|l|}{ Monte Carlo test: } \\
\hline Significance of $1^{\text {st }}$ axis $(p)$ & & 0.001 & & \\
\hline \multirow[t]{3}{*}{ Significance of all axes $(p)$} & & 0.001 & & \\
\hline & \multicolumn{2}{|c|}{ Intra-set correlation } & \multicolumn{2}{|c|}{ Canonical correlation } \\
\hline & Axis 1 & Axis 2 & Axis 1 & Axis 2 \\
\hline Transparency (tra) & 0.7993 & 0.3951 & 0.8550 & 0.5187 \\
\hline Macrophytes (mac) & 0.9319 & 0.0609 & 0.9968 & 0.0799 \\
\hline
\end{tabular}

in the ecosystems; this was most evident in the river, which had the most dispersed sampling units on this axis (Figure 4).

The high degree of species-environment correlation indicates that the species were highly associated with the sampling units. Moreover, both water transparency and macrophytes were positively correlated with Axis 1 (Table 4).
The ordination diagram in Figure 4 reveals that Bacillariophyta, E. pectinalis and Synedra minuscula Grunow were directly related to water transparency and associated with the reservoir sampling units. The Bacillariophyta Cyclotella sp. and Diploneis ovalis (Hilse) Cleve and the Cyanophyta Oscillatoria sp. and $G$. unigranulatum were directly related to macrophytes and associated with the river 

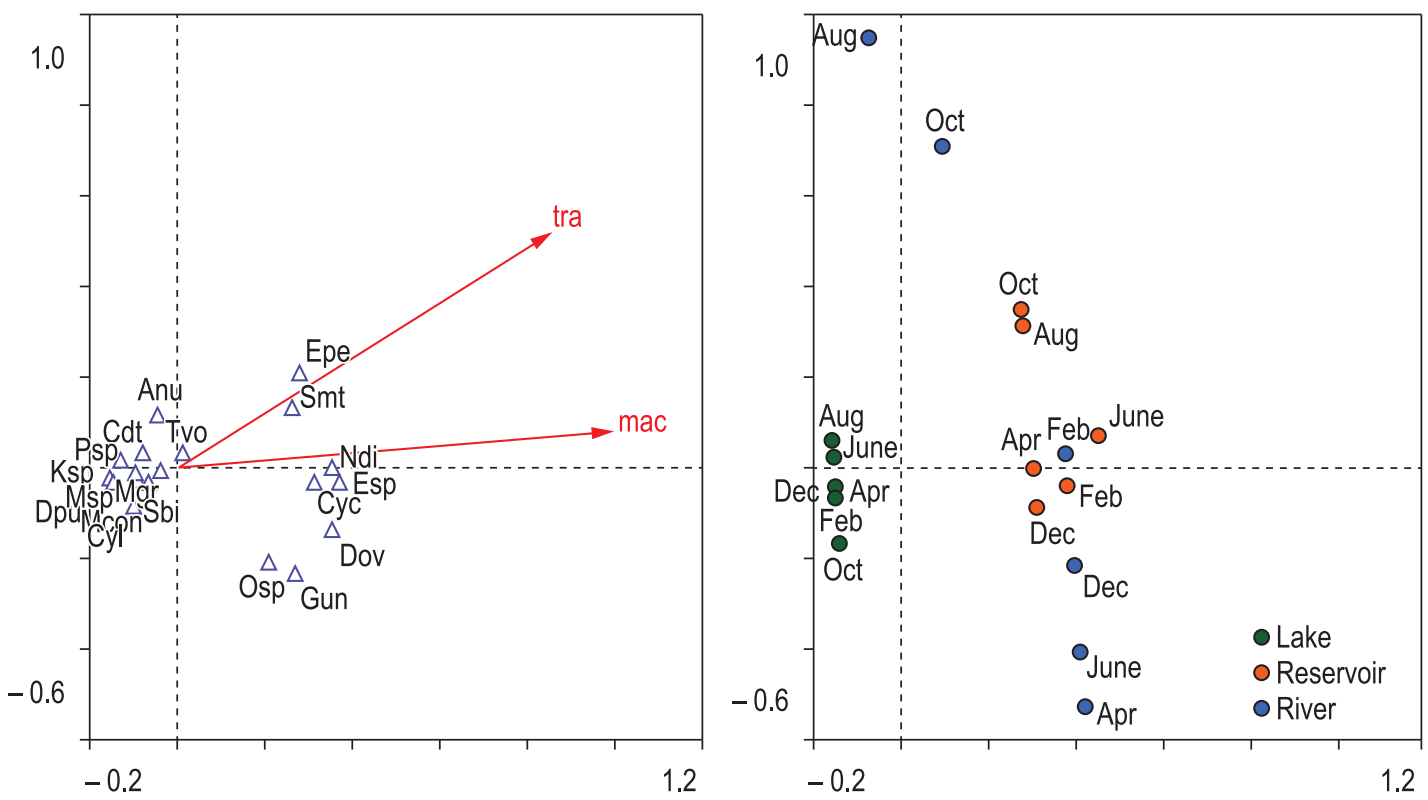

Figure 4. CCA ordination among main phytoplankton species and significant environmental factors in Solon de Lucena Lake, Águas Minerais reservoir and Jaguaribe River in metropolitan João Pessoa, PB, Brazil between Aug 09 and June 10: Legend: tra = Water transparency; mac = macrophyte infestation; Anu = Aphanocapsa nubilum; Cdi = Chroococcus dispersus; Cyc = Cyclotella sp.; Cyl = Cylindrospermopsis sp.; Dpu = Dictyosphaerium pulchellum; Dov = Diploneis ovalis; Epe = Eunotia pectinalis; Esp = Eunotia sp. 1; Gun = Geitlerinema unigranulatum; Ksp = Keratococcus sp.; Msp = Merismopedia sp.; Mcon = Monoraphidium contortum; Mgr = Monoraphidium Griffith; $N d i=$ Navicula dicephala; Osp = Oscillatoria sp.; Psp = Pseudanabaena sp.; Sbi = Scenedesmus bicaudatus; Smi = Synedra minuscula $;$ Tvo = Trachelomonas volvocina; Sampling units identified temporally with abbreviations $($ Aug $=$ Aug 09; Oct = Oct 09; Dec = Dec 09; Feb = Feb 10; Apr = Apr 10; June = June 10).

sampling units. The Bacillariophyta Eunotia sp. and $N$. dicephala were directly related to macrophytes and associated with the reservoir sampling units. The Cyanophyta A. nubilum, Chroococcus dispersus (Keissler) Lemmermann, Cylindrospermopsis sp., Merismopedia sp. and Pseudanabaena sp., the Chlorophyta Dictyosphaerium pulchellum H.C.Wood, Keratococcus sp., Monoraphidium contortum (Thuret) Komàrková-Legnerová, $M$. Griffith and Scenedesmus bicaudatus (Hansgirg) Chodat and the Euglenophyta Trachelomonas volvocina Ehrenberg were inversely related to water transparency and macrophytes and associated with the lake sampling units (Figure 4).

\section{Discussion}

Spatial heterogeneity of the environmental factors was only found between the aquatic ecosystems studied and was determined by water transparency, water temperature and macrophytes. According to Tucci and Sant'Anna (2003), banks of macrophytes contribute toward an increase in transparency. The reservoir and river exhibited a dominance of floating macrophytes, which impeded the stirring of the water by the wind, thereby contributing toward a reduction in turbulence and an increase in transparency. Likewise, the absence of macrophytes in the lake inversely affected water transparency in this environment and favored higher water temperatures in comparison to the other ecosystems, in which the presence of floating plants blocked the sunlight.

Regarding the phytoplankton, the high degree of beta diversity was a reflection of the difference in phytoplankton composition between ecosystems, with 30 of the 59 species (gamma diversity) occurring in only one of the ecosystems studied. This finding was related to the heterogeneity between the ecosystems, as also described by Nogueira et al. (2008) for the phytoplankton in four artificial urban lakes in the city of Goiânia, state of Goiás, Brazil.

Greater richness of Chlorophyta occurred in the lake, as reported for other lentic ecosystems (e.g., Espíndola et al., 1996; Taniguchi et al., 2003; Nogueira et al., 2005). The reservoir had a greater richness of Bacillariophyta. This division has also been reported to have a greater number of species in compartments with lotic characteristic both downstream and upstream from the Boa Esperança 
hydroelectric dam (states of Maranhão and Piauí, Brazil) (Pompêo et al., 1998). Bacillariophyta is among the groups with the greatest contribution to richness in Brazilian rivers (e.g., Borges et al., 2003; Rodrigues et al., 2007; Soares et al., 2007), as found for the river in the present study. In both Brazil and the entire world, the occurrence of phytoplankton in rivers is influenced by turbulence, which leads to the greater richness of Bacillariophyta (Reynolds et al., 1994).

The dominance of the cyanophyte Aphanocapsa nubilum in periods of greater overall density in the lake and river corroborates findings described in the majority of publications investigated by Huszar and Silva (1999). According to the authors, the dominance of Cyanophyta was found in 52\% of the Brazilian freshwater aquatic environments listed in these publications.

A temporal predominance in the density of Bacillariophyta was only found in the reservoir. Nogueira and Matsumura-Tundisi (1996) report the same in the reservoir of the Monjolinho Dam in the state of São Paulo, suggesting instability in these environments. According to Espíndola et al. (1996), the distribution of Bacillariophyta in the water column depends on turbulence, considering the ease of sedimentation exhibited by algae of this division.

CCA revealed that the variation in algal density between the ecosystems studied was influenced by water transparency and the degree of macrophyte infestation. Thus, unlike the other ecosystems, the lake was characterized by the absence of macrophytes, a low degree of water transparency and high algal density. Studying Garças Lake in the state of São Paulo, Crossetti et al. (2008) found that the expansion of floating macrophytes leads to competition among these plants for nutrients, leading to a reduction in algae and an increase in water transparency, whereas the opposite was found in phases without banks of macrophytes.

According to Padisák (1993), a low degree of diversity in any biological community may be caused by a low number of species or a low degree of evenness, which is related to the occurrence of dominant species. Thus, the lower diversity in the river may be attributed to the smaller number of species in comparison to the other ecosystems. However, the greater evenness in the reservoir was related to the non-occurrence of dominant species during the sampling period, which differs from the other ecosystems studied.
Regarding the interaction of environmental factors and taxa, Tucci and Sant'Anna (2003) found that low water transparency values in the absence of macrophytes in Garças Lake (São Paulo) were related to the dominance of Cyanophyta. The same was observed in the lake environment in the present study regarding the dominance of the cyanophyte $A$. nubilum, with an inverse relationship between this taxon and both water transparency and macrophyte infestation. The dominance of the cyanophyte Geitlerinema unigranulatum in the river environment is related to its metaphyte habit (Franceschini et al., 2010). Thus, algae of this species are loosely associated to aquatic banks and can participate in the phytoplankton, which was demonstrated by the direct relationship between this species and macrophytes.

The Bacillariophyta genera Eunotia and Navicula were abundant in the period of greater overall density in the reservoir and are commonly reported in the diatom flora attached to macrophytes (Bertolli et al., 2010; Silva et al., 2010). According to Taniguchi et al. (2005), macrophytes in the littoral region provide substrate for the development of algae and exportation can occur from the periphyton to the plankton. This situation in the reservoir was explained by the direct relationship Eunotia sp. and N. dicephala have with macrophytes.

In the present study, the phytoplankton structure was characterized by a greater richness of algae typical of instable ecosystems belonging to the division Bacillariophyta in the reservoir and river, thereby qualifying these ecosystems as lotic. In the lake, there was a floristic predominance of algae from the division Chlorophyta, which are typical of lentic environments with stiller waters. Water transparency and macrophyte infestation were inversely related to phytoplankton density in the different ecosystems studied. In the lake, the low degree was water transparency and absence of macrophytes favored the dominance of A. nubilum, causing greater overall density and lesser evenness in this ecosystem. The influence of macrophytes in the river and reservoir led to the introduction of metaphytes and epiphytes in the phytoplankton, which interfered in the abundance, evenness and diversity of these ecosystems.

\section{Acknowledgements}

The authors are grateful to the Universidade Estadual da Paraiba for its assistance in providing the resources necessary to the production of this study. 


\section{References}

ALVES-DA-SILVA, SM. and TAMANAHA, MS. 2008. Ocorrência de Euglenophyceae pigmentadas em rizipiscicultura na Região do Vale do Itajaí, SC, Sul do Brasil. Acta Botanica Brasilica, vol. 22, no. 1, p. 145-163.

AYRES, M., AYRES JUNIOR, M., AYRES, DL. and DOS SANTOS, AS. 2007. Manual BioEstat 5.0. Belém: Imprensa Oficial do Estado do Pará. 323 p.

BERTOLLI, LM., TREMARIN, PI. and LUDWIG, TAV. 2010. Diatomáceas perifíticas em Polygonum hydropiperoides Michaux, reservatório do Passaúna, Região Metropolitana de Curitiba, Paraná, Brasil. Acta Botanica Brasilica, vol. 24, no. 4, p. 1065-1081.

BICUDO, CEM. 2004. Criptógamos do Parque Estadual das Fontes do Ipiranga, São Paulo, SP. Algas, 18: Chlorophyceae (Volvocales). Revista Brasileira de Botânica, vol. 27, no. 1, p. 85-102.

BIOLO, S., SIQUEIRA, NS. and BUENO, NC. 2009. Chlorococcales (Chlorophyceae) de um tributário do Reservatório de Itaipu, Paraná, Brasil. Hoehnea, vol. 36, no. 4, p. 667-678.

BORGES, PAF, RODRIGUES, LC., PAGIORO, TA. and TRAIN, S. 2003. Spatial variation of phytoplankton and some abiotic variables in the Pirapó River -PR (Brazil) in August 1999: a preliminary study. Acta Scientiarum: Biological Sciences, vol. 25 , no. 1, p. 1-8.

BOZELLI, RL. and HUSZAR, VLM. 2003. Comunidades fito e zooplanctônicas continentais em tempo de avaliação. Limnotemas, no. 3, p. 32.

BRASSAC, NM. and LUDWIG, TAV. 2005. Amphipleuraceae e Diploneidaceae (Bacillariophyceae) da bacia do rio Iguaçu, PR, Brasil. Acta Botanica Brasilica, vol. 19, no. 2, p. 359-368.

CROSSETTI, LO., BICUDO, DC., BICUDO, CEM. and BINI, LM. 2008. Phytoplankton biodiversity changes in a shallow tropical reservoir during the hypertrophication process. Brazilian Journal of Biology, vol. 68, Suppl. 4, p. 1061-1067. http:// dx.doi.org/10.1590/S1519-69842008000500013

DÍAZ-CASTRO, JG., SOUZA-MOSIMANN, RM., LAUDARES-SILVA, R. and FORSBERG, BR. 2003. Composição da comunidade de diatomáceas perifíticas do rio Jaú, Amazonas, Brasil. Acta Amazonica, vol. 33, no. 4, p. 583-606.

ESPÍNDOLA, EG., MATSUMURA-TUNDISI, T. and MORENO, ID. 1996. Estrutura da comunidade fitoplanctônica da Lagoa Albuquerque (Pantanal Matogrossense), Mato Grosso do Sul, Brasil. Acta Limnologica Brasiliensia, vol. 8, no. 1, p. 13-27.

FERRAREZE, M. and NOGUEIRA, MG. 2006. Phytoplankton assemblages and limnological characteristics in lotic systems of the Paranapanema
Basin (Southeast Brazil). Acta Limnologica Brasiliensia, vol. 18, no. 4, p. 389-405.

FRANCESCHINI, IM., PRADO, JF. and BURLIGA, AL. 2010. Diversidade. In FRANCESCHINI, IM., BURLIGA, AL., REVIERS, B., PRADO, JF. and RÉZIG, SH. Algas: Uma abordagem filogenética,taxonômica e ecológica. Porto Alegre: Artmed. p. 73-213.

GERMAIN, H. 1981. Flore dês diatomées dês eaux douces et saumâtres. Paris: Société Nouvelle dês éditions Boubée. $444 \mathrm{p}$.

GROSS, EM. 2003. Allelopathy of Aquatic Autotrophs. Critical Reviews In Plant Sciences, vol. 22, p. 313-339. http://dx.doi.org/10.1080/713610859

HARRISON, S., ROSS, SJ. and LAWTON, JH. 1992. Beta diversity on geographic gradients in Britain. Journal of Animal Ecology, vol. 61, no. 1, p. 151-158. http://dx.doi.org/10.2307/5518

HUSZAR, VLM. and SILVA, LHS. 1999. A estrutura da comunidade fitoplanctônica no Brasil: cinco décadas de estudos. Limnotemas, no. 2, p. 1-21.

LANDUCCI, M. and LUDWIG, TAV. 2005. Diatomáceas de rios da bacia hidrográfica Litorânea, PR, Brasil: Coscinodiscophyceae e Fragilariophyceae. Acta Botanica Brasilica, vol. 19, no. 2, p. 345-357. http://dx.doi.org/10.1590/S010233062005000200018

LOBO, E. and LEIGHTON, G. 1986. Estructuras comunitarias de las fitocenosis planctonicas de los sistemas de desembocaduras de rios y esteros de la zona central de Chile. Revista Biologia Marina, vol. 22, p. 1-29.

MATEUCCI, SD. and COLMA, A. 1982. La Metodologia para el Estudo de la Vegetacion. Collecion de Monografias Cientificas, Série Biologia, no. 22, p. 168.

MELO, AST. 2001. Projeto de pesquisa vale do Jaguaribe. Coordenação de Geografia, UNIPÊ.

MOURA, AN., BITTENCOURT-OLIVEIRA, MC., MENDONÇA, DFP., OLIVEIRA, HSB., DANTAS, ÊW. and PIMENTEL, RMM. 2007. Microalgas e qualidade da água de manancial utilizado para abastecimento público localizado na região metropolitana da cidade do Recife, PE, Brasil. Revista de Geografia, vol. 24, no. 2, p. 154-178.

NOGUEIRA, NMC., BARBIERI, R., COSTA-NETO, JP. and ROCHA, O. 2005. Composition and temporal changes of phytoplankton community in Lake Quebra-Pote, MA, Brazil. Acta Limnologica Brasiliensia, vol. 17, no. 4, p. 419-431.

NOGUEIRA, MG. and MATSUMURA-TUNDISI, T. 1996. Limnologia de um ecossistema artificial raso (represa de Monjolinho - São Carlos, SP): Dinâmica das populações fitoplantônicas. Acta Limnologica Brasiliensia, vol. 8, no. 1, p. 149-168. 
NOGUEIRA, IS., NABOUT, JC., OLIVEIRA, JE. and SILVA, KD. 2008. Diversidade (alfa, beta e gama) da comunidade ftoplanctônica de quatro lagos artificiais urbanos do município de Goiânia, GO. Hoehnea, vol. 2 , no. 35, p. 219-233.

OZIMEK, T., GULATI, RD. and DONK, EV. 1990. Can macrophytes be useful in biomanipulation of lakes? The Lake Zwemlust example. Hydrobiologia, vol. 200-201, no. 1, p. 399-407. http://dx.doi. org/10.1007/BF02530357

PADISÁK, J. 1993. The influence of different disturbance frequencies on the species richness, diversity and equitability of phytoplankton in shallow lakes. Hydrobiologia, vol. 249, p. 135-156. http://dx.doi. org/10.1007/BF00008850

PIELOU, EC. 1977. Mathematical Ecology. New York: Wiley-Interscience. 385 p.

POMPÊO, MLM., MOSCHINI-CARLOS, V., COSTANETO, JP., CAVALCANTE, PRS., IBAÑEZ, MSR., FERREIRA-CORREIA, MM. and BARBIERI. R. 1998. Heterogeneidade espacial do fitoplâncton no reservatório de boa esperança (Maranhão-Piauí, Brasil). Acta Limnologica Brasiliensia, vol. 10, no. 2, p. 101-113.

REYNOLDS, CS., DESCY, JP. and PADISÁK, J. 1994. Are phytoplankton dynamics in rivers so different from those in shallow lakes? Hydrobiologia, vol. 289, p. 1-7. http://dx.doi.org/10.1007/BF00007404

RODRIGUES, SC., TORGAN, L. and SCHWARZBOLD, A. 2007. Composição e variação sazonal da riqueza do fitoplâncton na foz de rios do delta do Jacuí, RS, Brasil. Acta Botanica Brasilica, vol. 21, no. 3, p. 707-721.

SANT'ANNA, CL. 1984. Chlorococcales (Chlorophyceae) do Estado de São Paulo, Brasil. Bibliotheca Phycologica, no. 67 , p. 1-348.

SANT'ANNA, CL., MELCHER, SS., CARVALHO, MC., GEMELGO, MP. and AZEVEDO, MTP. 2007. Planktic Cyanobacteria from upper Tietê basin reservoirs, SP, Brazil. Revista Brasileira de Botânica, vol. 30, no. 1, p. 1-17.

SHANNON, CE. 1948. A mathematical theory of communication. Bulletin of System Tecnology Journal, vol. 27 , p. 379-423.

SILVA, LHS. 1999. Fitoplâncton de um reservatório eutrófico (Lago Monte Alegre), Ribeirão Preto, São
Paulo, Brasil. Revista Brasileira de Botânica, vol. 59, no. 2, p. 281-303.

SILVA, AM., LUDWIG, TAV., TREMARIN, PI. and VERCELLINO, IS. 2010. Diatomáceas perifíticas em um sistema eutró?co brasileiro (Reservatório do Iraí, estado do Paraná). Acta Botanica Brasilica, vol. 24, no. 4, p. 997-1016.

SOARES, MCS., HUSZAR, VLM. and ROLAND, F. 2007. Phytoplankton dynamics in two tropical rivers with different degrees of human impact (southeast Brazil). River Research and Applications, vol. 23, p. 698-714. http://dx.doi.org/10.1002/ rra.987

SØBALLE, DM. and KIMMEL, BL. 1987. A Large-Scale Comparison of Factors Influencing Phytoplankton Abundance in Rivers, Lakes, and Impoundments. Ecology Society Of America, vol. 68, no. 6, p. 19431954.

TANIGUCHI, GM., ROCHA, O. and SENNA, PAC. 2003. A comunidade fitoplanctônica de um lago tropical no sudeste do Brasil (Lago Dom Helvécio, estado de Minas Gerais). Caderno de Pesquisa, Série Biologia, vol. 15, no. 1, p. 29-55.

TANIGUCHI, GM., BICUDO, DC. and SENNA, PAC. 2005. Gradiente litorâneo-limnético do fitoplâncton e ficoperifíton em uma lagoa da planície de inundação do Rio Mogi-Guaçu. Revista Brasileira de Botânica, vol. 28, no. 1, p. 137-147.

TER BRAAK, CJF. and ŠMILAUER, P. 2002. CANOCO reference manual and CanoDraw for Windows user's guide: software for canonical community ordination. version 4.5. New York: Microcomputer Power. 500 p.

TRAIN, S., OLIVEIRA, MD. and QUEVEDO, MT. 2000. Dinâmica sazonal da comunidade fitoplanctônica de um canal lateral (Canal Cortado) do Alto Rio Paraná (PR, Brasil). Acta Scientiarum, vol. 22, no. 2, p. 389-395.

TUCCI, A. and SANT'ANNA, CL. 2003. Cylindrospermopsis raciborskii (Woloszynska) Seenayya \& Subba Raju (Cyanobacteria): variação semanal e relaçóes com fatores ambientais em um reservatório eutrófico, São Paulo, SP, Brasil. Revista Brasileira de Botânica, vol. 26, no. 1, p. 97-112.

VEGA, LMF. 1997. Contribución al estúdio de plantas acuáticas em embalses hidroeléctricos. El caso Itaipu (margen derecha). Biota, vol. 7, p. 1-45.

Received: 17 November 2011 Accepted: 04 May 2012 